\title{
A retrospective study to assess incidence of ectopic pregnancies in Saveetha Medical College and Hospital
}

\author{
S. K. Dheepthikaa, Rajalekshmi Murugan*
}

Department of Obstetrics and Gynaecology, SIMATS, Chennai, Tamil Nadu, India

Received: 11 September 2020

Revised: 15 October 2020

Accepted: 16 October 2020

\author{
*Correspondence: \\ Dr. Rajalekshmi Murugan, \\ E-mail: dr.raji@live.in
}

Copyright: () the author(s), publisher and licensee Medip Academy. This is an open-access article distributed under the terms of the Creative Commons Attribution Non-Commercial License, which permits unrestricted non-commercial use, distribution, and reproduction in any medium, provided the original work is properly cited.

\begin{abstract}
Background: Ectopic pregnancy is an acute abdominal emergency causing maternal morbidity and mortality. The overall incidence of ectopic pregnancy is increasing in recent times but due to early diagnosis and management the case fatality rate has reduced. Aim of the study is to determine the incidence of ectopic pregnancies in Saveetha hospital and find out common risk factors.

Methods: A retrospective study was conducted by analysing the medical records of the patients admitted in the Department of Obstetrics and Gynaecology for 4 years from January 2015 to 2019 at Saveetha hospital, Chennai. The number of ectopic pregnancies out of the total pregnancies and the risk factors causing the ectopic pregnancies were analysed based on case sheets by simple descriptive statistics and percentage method.

Result: Incidence was $3 \%$ or 30/1000 deliveries. The common age group was between 18 to 38 years. Mean age of ectopic pregnancy was 27.42 years. Risk factors were tubal ligation surgeries- $39.3 \%$, Intrauterine contraceptive devices (IUCD)-19.6\%, Pelvic inflammatory disease (PID)-16.1\%, infertility and ovulation induction-10.7\%, previous ectopic pregnancy and use of Oral contraceptive pills (OCP)-5.4\% and previous induced abortions-3.6\%.

Conclusion: Incidence of ectopic pregnancy is still remaining on the significant numbers. It can be diagnosed early by keeping a high index of suspicion. Tubectomy and other surgeries should be done with proper care. Education regarding safe abortion, unsupervised usage of OCP and risk of ovulation induction to avoid ectopic pregnancies.
\end{abstract}

Keywords: Ectopic pregnancy, Tubal ligation, OCP

\section{INTRODUCTION}

Ectopic pregnancy is one in every of the most typical acute abdominal emergencies a gynaecologist has got to meet in his practice. It's a very important reason for maternal morbidity and mortality especially in developing countries, where the bulk of patients present late with rupture and hemodynamic compromise. ${ }^{1}$

Ectopic gestation is due to result of a flaw in reproductive physiology of human body where the ovum implants and mature outside the endometrial cavity which ultimately ends in death of the foetus. ${ }^{2}$ Without timely diagnosis and treatment, pregnancy can become a life-threatening situation. However, it not only threatens the life, if not treated timely and effectively it might also affect her fertility unavoidably by causing mutilation of a necessary organ of reproduction, namely the fallopian tubes, ovary and sometimes even the uterus. . $^{3,4}$

Many pathological conditions present a percentage of variables but only some have greater disparity of symptoms, signs, opinions and reports as ectopic, which has made gestation a challenging problem, difficult to diagnose and manage. ${ }^{5}$ 
The general incidence of ectopic pregnancy is increasing within the past few decades but due to early diagnosis and management, the case death rate has come down. ${ }^{6}$ In spite of new diagnostic methods available most girls present late as majority of case are asymptomatic till they rupture. Gestation commonly occurs within the fallopian tubes $(97 \%){ }^{7}$ Although women with ectopic gestation frequently haven't any identifiable risk factors, a prospective and case controlled study has shown that increase awareness of gestation and knowledge of the associated risk factors like pelvic disease, history of previous ectopic gestation, tubal sterilisation and any previous pelvic or abdominal surgery help identifying women at higher risk so as to facilitate early and more accurate diagnosis. ${ }^{8}$

\section{Aim of the study}

The aim of the present study was to determine the incidence of ectopic pregnancies in Saveetha medical college and hospital and to find out the common risk factors causing the ectopic pregnancy.

\section{METHODS}

A retrospective study was conducted by analysing the medical records of the patients who were admitted in the department of Obstetrics and Gynaecology in Saveetha Medical College and Hospital, Chennai over a period of 4 years from January 2015 to January 2019. All ectopic pregnancies that reported during this time period were selected in chronological order from hospital records. It is a tertiary care centre getting referrals from nearby cities. The number of ectopic pregnancies out of the total pregnancies and the risk factors causing the ectopic pregnancies were analysed based on the case sheets after obtaining ethical approval. The labour room registers were used to determine the total number of deliveries during this period. The information of each patient was obtained from their case records kept in the medical records department. All relevant demographic data was obtained along with the cause of ectopic pregnancy. All data was analysed by simple descriptive statistics and percentage method. A total of 56 cases reported during this frame with ectopic pregnancy and were admitted at our hospital through emergency or outpatient department. The diagnosis of ectopic pregnancy was made mainly by history taking, clinical physical examination, laboratory tests such as urine pregnancy test, serum beta Human chorionic gonadotropin (HCG) and ultrasound investigations.

\section{Study design}

The study design was retrospective.

\section{Data collection}

Analysis of case records from the medical records department.

\section{Study place}

The study was conducted at Saveetha medical college and hospital.

\section{Study duration}

The study was conducted for 3 months.

\section{Inclusion criteria}

All confirmed cases of ectopic pregnancies from the January 2015 to January 2019 were included.

\section{Sample size}

Cases in the past four years from January 2015 to January 2019.

\section{Sampling technique}

Simple descriptive statistics and percentage method.

\section{RESULTS}

In the present study, which was conducted over a period of 4 years, the number of deliveries were 2045 and the total number of ectopic pregnancies were 56. Therefore the incidence of ectopic pregnancy was calculated to be $3 \%$ or 30 per thousand deliveries.

Table 1: Distribution of cases according to age.

\begin{tabular}{|lll|}
\hline Age (years) & $\%$ & $\mathbf{n = 5 6}$ \\
\hline$<\mathbf{2 0}$ & 5.3 & 3 \\
\hline $\mathbf{2 1}-\mathbf{2 5}$ & 28.57 & 16 \\
\hline $\mathbf{2 6}-\mathbf{3 0}$ & 35.71 & 20 \\
\hline $\mathbf{3 1}-\mathbf{3 5}$ & 25 & 14 \\
\hline $\mathbf{3 6}$ & 5.3 & 3 \\
\hline
\end{tabular}

The overall age group common for ectopic pregnancy was found to be between 18 to 38 . The mean age of ectopic pregnancy was 27.42 years. Around $5.35 \%$ of ectopic pregnancy occurred in age group less than 20 years.

Table 2: Distribution of cases according to risk factors $(n=56)$.

\begin{tabular}{|lll|}
\hline Risk factors & $\%$ & $\mathbf{N}$ \\
\hline $\begin{array}{l}\text { Previous tubal ligation } \\
\text { surgery }\end{array}$ & $39.3 \%$ & 22 \\
\hline Pelvic inflammatory disease & $16.1 \%$ & 9 \\
\hline Previous ectopic pregnancy & $5.4 \%$ & 3 \\
\hline Ovulation induction & $10.7 \%$ & 6 \\
\hline IUCD & $19.6 \%$ & 11 \\
\hline Previous induced abortion & $3.6 \%$ & 2 \\
\hline OCP use & $5.4 \%$ & 3 \\
\hline
\end{tabular}


$64.28 \%$ of cases were found to be between the age group 21-30 years and $30.35 \%$ above 30 years of age.

Among the 56 women who had ectopic pregnancies a majority of women, $39.3 \%$ or 22 cases were found to be due to previous tubal ligation surgeries (tubectomy). $19.6 \%$ or 11 of the 56 ectopic pregnancies had history of intrauterine contraceptive devices (IUD) and $16.1 \%$ or 9 out of 56 women had history of pelvic inflammatory disease (PID). Infertility and ovulation induction was found to be the cause for ectopic pregnancy in $10.7 \%$ or 6 of the total women with ectopic pregnancy. $5.4 \%$ or 3 out of 56 women had previous ectopic pregnancy and $5.4 \%$ or 3 cases had history of using oral contraceptive pills. $3.6 \%$ or 2 out of 56 cases had previous induced abortions.

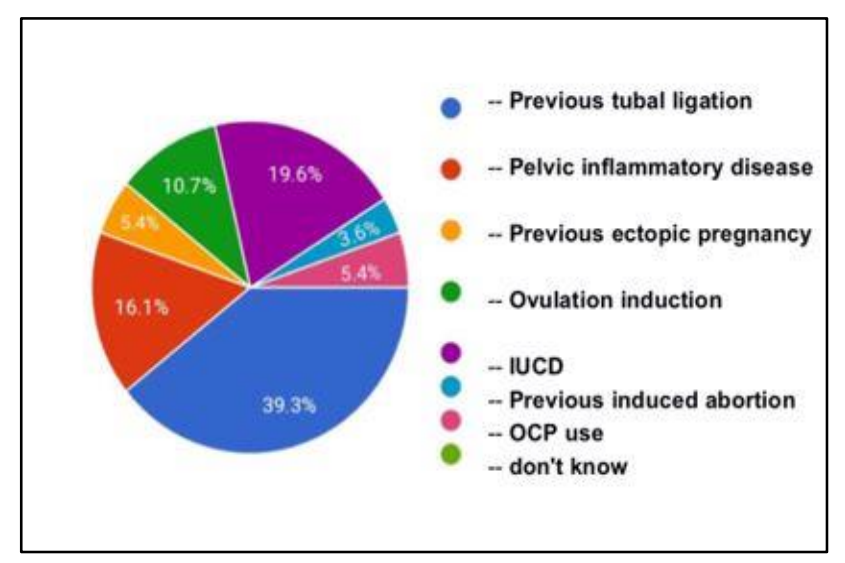

Figure 1: Percentage of risk factors of ectopic pregnancy.

\section{DISCUSSION}

Ectopic pregnancy could be a life-threatening emergency in obstetrics. It remains as a very important contributor to maternal morbidity and mortality and is one in all the most typical causes of 1 st trimester maternal deaths. The prevalence of ectopic pregnancy among women who head to an emergency department with first trimester bleeding, pain or both, varies from 6 to $16 \% .^{9,10}$ It accounts for 3.5$7.1 \%$ of maternal mortality in India. ${ }^{11,12}$ In India the incidence of ectopic gestation reported by the Indian council of medical research (ICMR) task force in their multi-centric case control study was 3.12 per 1000 pregnancies or 3.86 per 1000 live births within the hospital reported pregnancies.

Within the present study the incidence is $3 \%$. In other words the incidence is 30 per thousand deliveries which is important when put next to other studies. Within the present study majority of cases, $64.28 \%$ belonged to age group of 21-30 years which is almost like most of the studies from developing countries. The mean cohort commonly affected was 27.42 years. Younger cohort has high prevalence because they're more active sexually, predisposed to Sexually transmitted diseases (STD) and PID. Studies in USA, however reported an increasing incidence of pregnancy with advancing age. The difference observed in our country can be as a result of the very fact that ladies here enter in to married life earlier and end reproduction earlier too. Within the current study history of tubal surgery, including tubal sterilisation and tuboplasty, was the foremost commonly obtained risk factor seen in $39.3 \%$ of cases. Similarly, Singh et al have reported prior tubal surgery as a standard risk factor (40\%). ${ }^{13}$ Around 9 patients gave a history of PID which contributes to $16.1 \%$. Literature shows that PID is a very important factor predisposing to the event of eccyesis. In keeping with other studies done by Rose et al, Banks and Devi the incidence of PID as a risk factor is 4, 25 and $34.4 \%$ respectively. ${ }^{10,13,14}$ PID following gonococcal, chlamydial and other bacterial infection cause 3.3 to 6 fold increased risk of pregnancy. Many cases of chlamydia salpingitis are indolent cases which will go unrecognised causing tubal damage and subsequent ectopic pregnancy. ${ }^{15,16}$ Of these points create the identical fact into light that the recent change in sex life can cause pelvic inflammation and tubal damage in younger age groups causing more incidence of ectopic in young, nulli or low parity women. ${ }^{17,18}$

\section{Table 3: Comparison data of causes of ectopic pregnancy with previous studies}

\begin{tabular}{|c|c|c|}
\hline Risk factors & $\begin{array}{l}\% \text { in } \\
\text { present } \\
\text { study }\end{array}$ & $\begin{array}{l}\% \text { in } \\
\text { previous } \\
\text { studies }\end{array}$ \\
\hline $\begin{array}{l}\text { Previous tubal ligation } \\
\text { surgery }\end{array}$ & $39.3 \%$ & $40^{13}$ \\
\hline $\begin{array}{l}\text { Pelvic inflammatory } \\
\text { disease }\end{array}$ & $16.1 \%$ & $24^{19}$ \\
\hline $\begin{array}{l}\text { Previous ectopic } \\
\text { pregnancy }\end{array}$ & $5.4 \%$ & $3.2-20^{19}$ \\
\hline Ovulation induction & $10.7 \%$ & $48^{21}$ \\
\hline IUCD & $19.6 \%$ & $6.8^{20}$ \\
\hline $\begin{array}{l}\text { Previous induced } \\
\text { abortion }\end{array}$ & $3.6 \%$ & $21.05^{19}$ \\
\hline OCP use & $5.4 \%$ & $1.8^{15}$ \\
\hline
\end{tabular}

The incidence of ectopic with IUCD within the present study was $19.6 \%$. That's 11 patients have used intrauterine device which can cause ectopic pregnancy. Study done by Kharat et al shows that the incidence of IUCD as risk factor is $6.8 \% .^{20}$ Significant incidence of prolonged infertility and its causal relationship to ectopic pregnancy has been observed by various authors. Positive history of infertility was reported as high as $48 \%$ by Devi et al. ${ }^{21}$ But in present study only $10.7 \%$ of cases had history of infertility. Ovulation induction is that the main cause for ectopic pregnancies in infertility. So, the patients should be educated about the chance of ovulation induction and proper counselling should be done. In present study $5.4 \%$ of the cases have had the history of previous ectopic pregnancy. Recurrence of ectopic has been reported in various studies, ranging between $3.2 \%$ to $20 \%$. ${ }^{19}$ So, such patients have to be educated about the danger of 
recurrences. The current study shows a risk of 5.4 you tired of contraceptive pills utilized by the patients to stop conception and three. $6 \%$ risk of ectopic gestation was found to be with previous history of abortions. It might be induced or miscarriages but within the study it absolutely was most ordinarily abortion which had higher risk than spontaneous abortion. Thus, women with previous abortion should be counselled and cared for the chance of pregnancy.

\section{CONCLUSION}

Incidence of ectopic pregnancy has increased over past few years and remains in high numbers. Ectopic pregnancy continues to be a significant challenge in obstetrical practice due to its bizarre clinical presentation and is one of the most common causes of pregnancy related deaths within the first trimester. It may be diagnosed early by keeping a high index of suspicion. Despite exhaustive efforts to reduce ectopic the numbers are constantly rising because of increased reporting of the cases and improved diagnostic modalities. Delay in referral causes significant morbidity and diminishes the probabilities of preserving future fertility. Tubectomy and other surgeries should be through with proper care. Mass education regarding safe abortion practices and post abortal care should be promoted. Unsupervised usage of Medical termination of pregnancy (MTP) pill intake should be condemned. Risk of ovulation induction and tubectomy should be educated to avoid ectopic pregnancies.

Funding: No funding sources Conflict of interest: None declared

Ethical approval: The study was approved by the Institutional Ethics Committee

\section{REFERENCES}

1. Sudha VS, Delphine RT. A retrospective study on ectopic pregnancy: a two year study. Int J Reprod Contracept Obstet Gynecol. 2016;5:4365-8.

2. Gary CF, Leveno KJ, Bloom SL, Hauth JC, Rouse DJ, Spong CY. Williams Obstetrics. Ectopic pregnancy. 23rd edition. The Mc Grew-Hill Companies. 2010;238-54.

3. Mahboob U, Mazhar SB. Management of ectopic pregnancy: a two-year study. J Ayub Med Coll Abbottabad. 2006;18(4):34-7.

4. Ectopic pregnancy-United States, 1990-1992. Centers for disease control and prevention. JAMA. 1995;273:533.

5. Rajkhowa M, Glass MR, Rutherford AJ, Balen AH, Sharma V, Cuckle HS. Trends in the incidence of ectopic pregnancy in England and Wales from 1966 to 1996. BJOG. 2000;107:369-74.

6. Stovall TG, Ling FW, Buster JE. Outpatient chemotherapy of unruptured ectopic pregnancy. Fertil Steril. 1989;51:435-8.

7. Stovall TG, Ling FW, Gray LA, Carson SA, Buster JE. Methotrexate treatment of unruptured ectopic pregnancy: A report of 100 cases. Obstet Gynecol.1991;77:749-53.

8. Vasquez G, Winston RML, Brosens IA. Tubal mucosa and ectopic pregnancy. BJOG. 1983;90:468.

9. Karaer A, Avsar FA, Batioglu S. Risk factors for ectopic pregnancy: a case-control study. Aust N Z J Obstet Gynaecol. 2006;46:521-7.

10. Shetty S, Shetty A. A clinical study of ectopic pregnancies in a tertiary care hospital of Mangalore, India. Innov J Med Health Sci. 2014;4(1):67-72.

11. Shah P, Shah S, Kutty RV, Modi D. Changing epidemiology of maternal mortality in rural India: time to reset strategies for MDG-5. Trop Med Int Health. 2014;19(5):568-75.

12. Yadav K, Namdeo A, Bhargava M. A retrospective and prospective study of maternal mortality in a rural tertiary care hospital of Central India. Indian $\mathbf{J}$ Community Health. 2013;25(1):16-21.

13. Singh S, Mahendra G, Vijayalakshmi S, Pukale RS. Clinical study of ectopic pregnancy in a rural setup: A two year survey. Natl J Med Res. 2014;4(1):37-9.

14. Udigwe GO, Umeononihu OS, Mbachu II. Ectopic pregnancy: a 5 year review of cases at nnamdiazikiwe university teaching hospital (NAUTH) Nnewi. Niger Med J. 2010;51(4):160.

15. Khaleeque F, Siddiqui RI, Jafarey SN. Ectopic pregnancies: A three year study. J Pak Med Assoc. 2001;51(7):240-2.

16. Wakankar R, Kedar K. Ectopic Pregnancy-A rising Trend. Int J Sci Stud. 2015;3(5):18-22.

17. Rose J, Thomas A, Mhaskar A. Ectopic pregnancy: Five years experience. J Obstet Gynecol India. 2002;52:55-8.

18. Majhi AK, Roy N, Karmakar KS, Banerjee PK Ectopic pregnancy: an analysis of 180 cases. J Indian Med Assoc. 2007;105(6):308-12.

19. Shaikh S, Jampala S, Devi S, Malika M. A study of ectopic pregnancy in a tertiary care teaching hospital. Indian J Obstet Gynecol Res. 2016;3(2):132-6.

20. Kharat D, Giri PG, Fonseca M. A study of epidemiology of ectopic pregnancies in a tertiary care hospital of Mumbai, India. Int J Reprod Contracept Obstet Gynecol. 2017;6:3942-6.

21. Savitha Devi Y. Laparoscopic treatment of ectopic pregnancy. J Obst Gyn India. 2000;50:69.

Cite this article as: Dheepthikaa SK, Murugan R. A retrospective study to assess incidence of ectopic pregnancies in Saveetha Medical College and Hospital. Int J Reprod Contracept Obstet Gynecol 2020;9:4632-5. 